\title{
Modern demands of education quality management in a higher education institution
}

\section{Сучасні запити управління якістю освіти у закладі вищої освіти}

Received: April 5, 2021

The article is devoted to the analysis of modern demands of education quality management in the conditions of higher education institution operation. The methodological basis of the study is the concept of management, based on a system of philosophical and general scientific doctrines about the quality of education and its specifics in higher education, the concept of personalityoriented learning, systems theory, modeling and development. The authors systematized methodological approaches to modeling the quality management system of education in higher education. The study developed a model of quality management, which is presented at the levels of: subsystems of management approaches, theoretical and methodological foundations, the value of the components and factors of education of different nature; defined a system of principles of internal quality management of higher education, aimed at performing a regulatory function at the general scientific, strategic, practice-oriented, technical, specific scientific and factor levels; an algorithm for building an education quality management system in a higher education institution is presented. It is shown that the quality management of education should be carried out at levels that ensure the manufacturability of the process, the possibility of its improvement with
Accepted: May 7, 2021

Written by:

Serhii Dieniezhnikov ${ }^{15}$ https://orcid.org/0000-0003-3289-8399

Liubov Pshenychna ${ }^{16}$ https://orcid.org/0000-0002-2840-2189

Dmitro Kozlov ${ }^{17}$

https://orcid.org/0000-0003-1875-0726

Olena Kozlova ${ }^{18}$

https://orcid.org/0000-0003-1626-5188

\begin{abstract}
Анотація
Стаття присвячена аналізові сучасних запитів управління якістю освіти в умовах роботи закладу вищої освіти. Методологічною основою дослідження виступає концепція управління, заснована на системі філософських та загальнонаукових вчень про якість освіти та і1 специфіку у закладах вищої освіти, концепції особистісно-орієнтованого навчання, теорії систем, ïх моделювання та розвитку. Автори систематизували методологічні підходи до моделювання системи управління якістю освіти у закладі вищої освіти. В дослідженні розроблено модель управління якістю, яка представлена на рівнях: підсистем управлінських підходів, теоретичних та методологічних основ, ціннісної сутності компонентів та факторів освіти різного характеру; визначено систему принципів внутрішнього управління якістю вищої освіти, цілеспрямовану на виконання регуляторної функції на загальнонауковому, стратегічному, практикоорієнтованому, технічному, конкретно-науковому та факторному рівнях; представлено алгоритм побудови системи управління якістю освіти у закладі вищої освіти. Показано, що управління якістю освіти має здійснюватися на рівнях, що забезпечують технологічність процесу, можливість його вдосконалення 3 подальшим аналізом отриманих результатів і прийняттям відповідних управлінських рішень.
\end{abstract}

${ }^{15} \mathrm{PhD}$ in Philosophy, Associate Professor of Department of Management of Education and Pedagogy of Higher School, Sumy Makarenko State Pedagogical University, Sumy, Ukraine.

$16 \mathrm{PhD}$ in State Management, Professor of Department of Management of Education and Pedagogy of Higher School, Sumy Makarenko State Pedagogical University, Sumy, Ukraine.

${ }^{17}$ DSc in Pedagogy, Associate Professor of Department of Management of Education and Pedagogy of Higher School, Sumy Makarenko State Pedagogical University, Sumy, Ukraine.

${ }_{18} \mathrm{PhD}$ in Pedagogy, Professor of Department of Management of Education and Pedagogy of Higher School, Sumy Makarenko State Pedagogical University, Sumy, Ukraine. 
further analysis of the results and the adoption of appropriate management decisions.

Keywords: methodology, quality of education, education quality management, institution of higher education.

\section{Introduction}

The most important indicator of the effectiveness of investment in education is its quality. And since the main potential of innovative development of Ukraine is concentrated in higher education institutions and its level is directly determined by the quality of higher education, one of the main directions of modernization of education in Ukraine is the development of variable models of quality management in higher education.

Since the problems of quality of education in modern society are very important in terms of training a competitive specialist, optimizing the management of the educational process, as well as entering the international market of educational services, the issues of forming a quality assurance system are especially relevant.

The concept of education quality management is a complex goal-oriented system of theoretical and methodological, technological knowledgemeanings, based on the principles of synergetic approach, accumulating promising areas of education based on understanding quality as a universal metafactor, allowing to integrate paradigmatic and partial subject knowledge into a single whole.

The decomposition of the goals of the quality management system of education in a higher education institution is presented at the level of general and partial goals, reflecting the strategic approach to continuous quality improvement, known in the theory and practice of quality management. Reliance on the philosophy of quality of education ensures the development of higher education institutions based on increasing innovation potential, which is based on the harmony and balance of change processes.

The purpose of the article is to describe the methodological principles of quality management of education in a modern higher education institution.

\section{Literature Review}

The problem of effective management of higher education institutions in market relations
Ключові слова: методологія, якість освіти, управління якістю освіти, заклад вищої освіти.

becomes especially relevant with the emergence of new requirements for higher education institutions in the market of educational services and the labor market, a full participant in which is a modern educational organization and is studied in the works of O. Zabolotna (2014), N. Bilokonenko (2018), M. Us (2018) and others.

The processes of economic globalization, the problems of our state's entry into the international educational space require the solution of issues of systemic quality assurance of professional training in the conditions of higher education institution are investigated in the works of I. Annenkova (2010), O. Garashchuk (2019), L. Harutyunyan (2012), L. Pshenichnaya (2019).

K. Korsak (2020), N. Labus (2018) and B. Zhitnik (2020) search the correlation of target settings of development of higher education institution with the state educational policy.

Intensification of integration processes in the spheres of education, science, culture and production in the context of ensuring the quality of education and increasing the competitiveness of educational structures are analyzed in the works of V. Bilokopitov (2013), M. Korodenko (2019), D. Shulikin (2018) and P. Sikorsky (2019).

However, the work of these researchers does not show that higher education institutions have the following tasks: correlation of target settings for the development of higher education institutions with the state educational policy, one of the directions of which is to create a state system of quality assurance and evaluation; creation of mechanisms that ensure the quality of educational services provided by higher education institutions; intensification of integration processes in the fields of education, science, culture and production in the context of ensuring the quality of education and increasing the competitiveness of educational structures.

Without solving these problems, it is impossible to implement a program of modernization of the Ukrainian education system within the framework of a single socio-economic policy of 


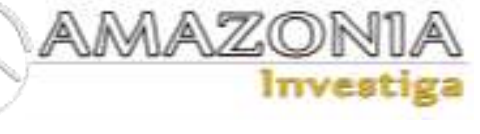

the state, aimed at solving the problem of ensuring the quality of training of modern specialists.

\section{Methodology}

Methodological and theoretical foundations of the study were: philosophical teachings about quality; theories of professional pedagogy, socialization and professionalization of the individual in the process of learning, integration and differentiation of professional training; concepts of development of education methodology; concepts of pedagogical design and modeling of educational systems and technologies; the concept of personality-oriented education and personality as the highest value; systems theory and principles of their modeling and development; general principles and patterns of management theory in social systems; ideas of management of educational process; the concept of general quality management; methodology of general qualimetry of education; theoretical bases of quality assessment of educational services; provisions on the essence of the pedagogical process from the standpoint of acquiring the properties of integrity, management of innovation processes; provisions on the principles of formation of the modern labor market and long-term needs for specialists.

Research methods: theoretical analysis of the research problem based on the study of philosophical, pedagogical and methodological literature; analysis of legislative and normative acts and documents, educational standards, qualification characteristics, etc. in order to study the nature and content of the quality of education, clarification of the requirements for its professionally significant characteristics; synthesis of theoretical ideas on the problem; socio-pedagogical modeling and pedagogical design; diagnostics of training quality; statistical methods of processing research results.

\section{Results}

The current stage of development of national education is characterized by profound changes caused not only by socio-economic and political circumstances, but also by deeper general civilizational changes. A visible expression of the transformations of higher professional education is the growth of requirements for its quality, the intensification of competition in the market of educational services. Further ways of improvement underlie the development of the European space.
Adhering to the strategic goal of the Bologna Process - improving the quality of higher education, increasing its competitiveness - it is important not to lose the rich experience that has been accumulated by domestic higher education institutions over its long history. We share the opinion of researchers that any participation of higher education of Ukraine in the Bologna process should be a factor in increasing and developing, rather than losing positive traditions and lowering national standards of its quality (Zhitnik, 2020).

All the above is a sufficient basis for active search and widespread implementation of effective ways to improve the quality of training in higher education institutions. The solution to this problem is seen in the institutional guarantee of the quality of higher education institutions. This approach will allow each institution of higher education to actively and creatively address this issue.

Analysis of the practical activities of domestic higher education institutions allows us to identify the most common problems:

- there are no uniform requirements, criteria for quality management of higher professional education;

- unadapted transfers of the requirements of the international quality standards developed for the sphere of material production to the sphere of education are carried out;

- dominated by technologies aimed at obtaining quantitative results, the predominant actualization of external incentives for quality improvement, etc.;

- there is no single pedagogical concept of using a systematic approach to the design and management of educational systems (Plaskura, 2018).

In this regard, it is important to understand the main features of the system. In modern scientific research, this concept is interpreted as something whole, representing the unity of naturally located and interconnected parts. The system is a set of elements that are in relationships and connections with each other, which forms a certain integrity, unity. Thus, the main features of the concept of "system", is the presence of a set of parts (elements), their regular location relative to each other, integrity. There is a need to consider the goals, objectives, set of functions, structure, its relationship between the components of the quality management system of education (Zabolotna, 2014). 
Given these requirements, we will consider the university system of education quality management as a system that promotes targeted impact on the educational process, capable of continuous development, focused on optimal creation of conditions for effective training of a competent specialist (Garashchuk, 2019).

Let's turn to the characteristics of the university system of education quality management:

- in the presence of interaction with the environment - open, because "there is a constant exchange of information with the environment";

- on the ability to distinguish between real systems (objects, phenomena, processes) and systems that are certain reflections (models) of real objects - abstract;

- in the presence of constancy of the state of the system in time - dynamic;

- in the presence of the main body centralized;

- in the presence of the purposes of functioning - artificial (Us, 2018).

Essential properties in accordance with the representation of the education quality management system as a semantic model can be conditionally classified not only by the level of complexity, but also by belonging to the systemforming (system-wide), structural or functional groups (Labus, 2018).

Let's highlight the main system-wide properties for the university system of education quality management:

- integrity - the education quality management system covers all components of the training process - goals, content, technology and results;

- relationship - quality indicators in each group, is a prerequisite for determining quality indicators in another group, with links between groups of indicators direct and inverse;

- dynamism - indicators in each group are constantly changing, while influencing each other (Bilokonenko, 2018).

The education quality management system has a purposeful nature, which determines the need to identify the main objectives of its activities.

The purpose of the university quality management system is to ensure compliance with the results of higher education institutions to the established requirements of the standard at all stages of professional training of graduates, taking into account the needs of secondary schools, individuals, society as a whole (Shulikin, 2018).

Development and improvement of the education quality management system is carried out on the basis of standards, the characteristic features of which are the application of process approach, documentation management, implementation of TQM principles, building organizational structure, conducting internal audits, selfassessment of higher education institution and its structural units.

The application of the process approach involves the scientific substantiation of processes, identification of the input and output of the process; development of its stages, definition of control measures, methods of measurement and analysis of quality characteristics (Korsak, 2020).

As the main processes in the context of our study, we have identified six basics: marketing, design and development of educational programs, admission of students, implementation of basic educational programs, educational and extracurricular work with students, research and development.

All quality management system procedures are documented. The list of required documents is presented in four levels.

The first level. Conceptual documents: "Quality Policy", "Mission and Vision of a Higher Education Institution", “Quality Objectives', "Concept of Higher Education Institution Development", documents describing the education quality management system, "Guidelines for the quality of a higher education institution (structural units)".

The second level. Documented methods: documented methods of management at the level of higher education institution (structural units): documentation management; record management; internal audits; corrective and preventive actions.

The third level. Management documentation that ensures the effectiveness of the management cycle: administrative, regulatory, training, information and reference documentation.

The fourth level. Reporting documentation: records on the results of internal audits of the education quality management system, analytical 


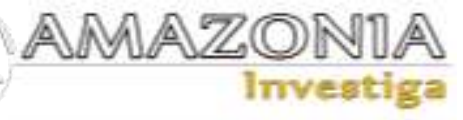

reports of the monitoring department, information and analytical bulletins, questionnaires of students, teachers, employers, for which the higher education institution prepares graduates.

Highlight the principles that must be considered in the process of education quality management. An analysis of the scientific review suggests that one of the system-forming factors, the "categorical framework", which carries large prognostic functions, are the principles of the system. They, being the "basis of the system", as regulators, set the "course" of the processes.

In our study, we will consider the principles as axiomatically given starting points, corresponding to the essence of the effective formation of the competence of future graduates. Under the general principles of quality management, we will take into account the generally accepted principles of quality management in management theory: customer orientation, leadership, staff involvement, process approach, systematic approach to management, continuous improvement, factbased decision making, mutually beneficial relationships with suppliers (partnerships with educational institutions) (Korodenko, 2019).

Addressing the idea of improving the quality of education in higher education institution in the analysis of modern approaches allowed to formulate their own empirically developed principles that can form the basis of constructive predictive scientific theory of management in education not only technological but also humanitarian institutions of higher education: principles of integrated approach, coherence of actions of subjects of educational process, humanization, development and selforganization of management system of quality of education, objectivity and completeness of information (Garashchuk, 2019a).

Quality management is a multicomponent pedagogical phenomenon of complex nature, which is an integrative integrity and has structural levels of its organization. On this basis, we can identify the functional and organizational structure of the university system of education quality management (Pshenichnaya, 2019).

The functional structure is a dynamic integrity, integrating the interaction of two subsystems: procedural (target, content, technological, organizational, resource support) and the resulting (control and evaluation of the quality of graduate training) (Sikorsky, 2019).
The development of an education quality management system should be level-organized. We fully share the view of the simplest hierarchy in the system: the control and managed subsystems. It is important to determine the purpose of the function of each subject of the educational process, the criteria for the quality of their activities.

The accumulated practical experience allowed to distinguish the organizational structure, which can be considered as a set of hierarchically structured components from the position of the manager (Academic Council of Higher Education Institution, Rectorate, Department of Education Quality Monitoring) and managed subsystems (faculties, graduating and interfaculty marketing department, institutions where the practice is carried out) (Annenkova, 2010).

Management of the quality of education at the university is carried out taking into account the criteria, which covers in unity both the quality of the result and the quality of the process. Criteria of quality of result of educational process allow to define a level of preparation of future graduates, and criteria of quality of process - to carry out coordination of activity of all subjects of educational process on realization of purposeful influences on process.

Let's define activity of subjects in the field of quality of education taking into account procedural and result characteristics:

- Rectorate. Quality activities: defining the strategy of the higher education institution; program development in the field of quality; designing a strategy and policy in the field of quality for the structural units of the institution of higher education. Quality criteria: result: compliance of student training results with the requirements of state educational standards; meeting the needs of "stakeholders": students, their parents, employers; high rating among other higher education institutions; process: compliance with the actual quality of training of graduates of the desired (ensuring the quality of purpose, content, learning technologies).

- Educational and methodical management. Activities in the field of quality: adaptation of the requirements of the state educational standard in accordance with the specifics of the institution of higher education, the demands of the labor market. Quality criteria: result: representation in educational 
and methodical complexes of technologies of assessment of quality of preparation of students; process: compliance with basic educational programs, curricula; educational and methodical complexes, manuals to the state educational standards; organization of different types of practices.

- Education Quality Monitoring Department. Activities in the field of quality: general organization of monitoring research; analysis of the obtained results; preparation of proposals for the correction of the educational process for the administration; development of recommendations for structural units. Quality criteria: result: monitoring of the quality of the entrant's potential; educational achievements of students in the periods of current, boundary sections; graduate training; identification of graduates' satisfaction with the received education; process: the quality of the organization of the learning process: the provision of resources (educational and methodological, logistical, technological, etc.), identifying the conditions created for students, teachers; assessment of employers' satisfaction with the professional competence of a young specialist.

- Faculty. Quality activities: development of a program of measures in the field of quality in accordance with the strategy of the institution of higher education; organization of monitoring the quality of student training: analysis of the results (current, boundary, final control) of students' academic achievements, their personal qualities; implementation of the management cycle at the faculty. Quality criteria: result: academic achievements of students of the faculty during the current control (intermediate certification), boundary control (results of sessions), residual knowledge of students (external verification during the Internet exam); process: coordination of actions of subjects of educational process at faculty; the quality of the organization of the educational process.

- Chair. Activities in the field of quality: compliance with the requirements for the implementation of basic educational programs; correction of the content, methods and techniques of training in accordance with the results of monitoring; development of requirements for the quality of teaching disciplines; implementation of feedback in the process of student learning; quality control of the department by areas. Quality criteria: result: the quality of implementation of basic educational programs that ensure the competence of future professionals; monitoring the quality of teaching; compliance with the requirements of educational and methodical materials of the department; process: the quality of training of teaching staff for classes; quality of educational-methodical, material-technical, organizational support of educational process.

- Student. Activities in the field of quality: participation in the assessment of conditions created for the study of students in higher education institution (quality of training, quality of teaching, satisfaction with the quality of education received, etc.). Quality criteria: result: competitiveness of the graduate in the labor market.

Education quality management should be carried out at a level that ensures the manufacturability of the process, the possibility of its improvement with further analysis of the results and the adoption of appropriate management decisions (Harutyunyan, 2012).

Technological bases of education quality management can be presented as wellestablished in management a certain sequence of stages: analysis, definition of management goals, planning, implementation, control, decisionmaking, correction, which are subject to training goals, mission of a particular higher education institution, which determines the features of the educational process and the nature of its educational environment (Bilokopitov, 2013).

Goal setting is crucial for all stages of the management cycle. The presented stages, successively changing each other, form a cycle of actions: the result of the last stage fills with the maintenance the following, efficiency of realization of one stage influences realization of the further (Boichenko, 2017).

Taking the classification of management functions, let's change the order of their location and show their interdependence with the stages of the management cycle:

- The information-analytical function provides regular information on the quality of the educational process and analysis of the data obtained;

- Motivational-target function promotes the interaction of all subjects of the educational process, which allows the coordinated choice of goals at different levels of the hierarchy; 


\section{AMAZONDA}

- Planning and forecasting function helps to determine the prospects for the development of the studied object;

- Organizational and executive function contributes to the implementation of effective management on the basis of scientific organization of the management cycle;

- The control-diagnostic function provides a comprehensive assessment of the quality of education at all its stages using diagnostic methods;

- Regulatory and corrective function provides correction of education quality management taking into account the principle of "decision-making based on facts".

All management functions are closely related and reflect the logic of the quality management process of the educational process. Let's imagine the stages of the management cycle, taking into account the relationship of the selected functions of education quality management in higher education institution.

Based on the above research, we can suggest the algorithm of the education quality management system.

The algorithm of the education quality management system can include in itself several components

\begin{tabular}{|c|}
\hline Content component \\
\hline $\begin{array}{c}\text { formation of an idea of the quality of education; } \\
\text { methodological approaches to quality assessment; } \\
\text { analysis of the quality of education; } \\
\text { determination of goals, objectives and directions; }\end{array}$ \\
development of the Program of the university system for assessing the quality of education. \\
\hline Management component \\
public administration system; \\
system of methodological activity; \\
a system of socio-psychological, educational activities; \\
system of control and evaluation, expert activities.
\end{tabular}

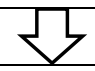

The technological component consists of invariant (regional,

municipal) and variable (university) assessment technologies and can contain the following technologies

technologies for accounting, processing and transfer of special management
information (control and supervisory technologies).
technologies for socio-economic monitoring of the quality of education
(monitoring technologies).
technologies for social and pedagogical monitoring of the quality of education
(monitoring technologies).

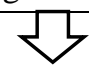

The organizational and activity component of the university system for assessing the quality of education is formed on the basis of a system of indicators, a bank of diagnostic techniques, control and measuring materials, with the help of which:

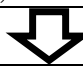

monitoring system.

the system of social and pedagogical diagnostics. intraschool control system.

the system of attestation of teaching staff.

the system of public expertise. 


\section{Discussion}

The results of the study are to develop an algorithm for building a quality management system for education, focused on innovative search and development of higher education, which increases the competitiveness of graduates in the labor market. The results of the study can be used in the construction of variable models of quality management at the institutional level. The reliability and validity of the main provisions and conclusions of the study is ensured by the research methodology, adequate to the subject, purpose, objectives, methodological positions, consistency in the implementation of theoretical provisions, parametric data, the effectiveness of the implemented quality management system at the institutional level. The results of the study can be used by managers and teaching staff of innovative educational institutions and higher education institutions for strategic planning of their activities; definition of the purposes, mission, prospects of development of higher school as the organization; creation of educational quality systems that reflect the specifics of the educational institution.

\section{Conclusions}

The analysis of practical activity allows to draw a conclusion that the offered organization of activity on management of quality of educational process has necessary system, depth; allows you to correlate the real state of affairs with what was planned; timely make appropriate management decisions to correct the process of training future graduates in order to improve it.

In the future, it is planned to conduct selfassessment of quality models, assess the level of maturity of the education quality management system, which helps to determine the effectiveness of quality management of education in accordance with accepted standards and recommendations for quality of higher education in the European educational space.

It is promising to continue the study, taking into account the justification of the taxonomy of the goal for each stage of the management cycle, functions, monitoring methods, the activities of the subjects of the educational process, as well as regular internal quality audits.

The functioning of the quality management system of education in higher education is carried out in an appropriate information and analytical environment, which must meet the following requirements: the functioning and development of the system and all its elements is in full agreement with the functioning of interacting systems, thus achieving the expected goals; in the process of interaction, each system strives for self-survival and balanced development; the system maintains and enriches its own energy and information balance due to those systems with which it interacts with the help of stabilized feedback; elements of the system must be dynamic, be able to move from one state to another; the system must be focused on achieving a result sufficient for its operation and further development.

The great importance is the stability of the information environment (leveling entropy), provided by the presentation of formalized components of the quality management system based on the creation of information-analytical environment using modern educational technologies.

\section{Bibliographic references}

Annenkova, I.P. (2010). Analysis of the main approaches to determining the quality of education. Pedagogical sciences: theory, history, innovative technologies, 4(6), 239-248, https://pedscience.sspu.sumy.ua/?page_id=1611 Bilokonenko, N. (2018). External Rating Evaluation as a Tool For Internal Quality Assurance System in Higner Education Institution. Pedagogical sciences: theory, history, innovative technologies, 10(84), 3-21, http://www.repository.hneu.edu.ua/bitstream/12 3456789/20515/3/Белоконенко.pdf Bilokopitov, V.I. (2013). Ensuring the quality of higher education: the European level of cooperation. Pedagogical sciences: theory, history, innovative technologies, 4(30), 85-93, https://repository.sspu.edu.ua/bitstream/123456 789/1974/1/Bilokopytov\%20Vasyl\%20Ivanovy ch.pdf

Boichenko, M.A. (2017). Innovative approaches to ensuring quality of educational services for gifted schoolchildren in the USA, Canada and the UK. Actual problems of quality management of education: theory, history, innovative technologies: monograph, 35-70, https://pedscience.sspu.edu.ua/wp-

content/uploads/2020/02/монографія_2017_зві T.pdf

Garashchuk, O. (2019). Challenges and risks on the way to quality education. Education management, $7, \quad 26-45$, http://www.osvitaua.com/shop/newspapers/uog/ uog-2019-007/

Garashchuk, O. (2019a). Effective management of quality of education in the conditions of 


\section{AMAZONDA}

decentralization: methodical aspects. Education management, 7 , 54-65, http://www.osvitaua.com/shop/newspapers/uog/ uog-2019-007/

Harutyunyan, L.V. (2012). Profile training as a condition for improving the quality of education. A gifted child, 10, 2-8, http://lib.ndu.edu.ua/cgibin/irbis64r_12/cgiirbis_64.exe?LNG $=\& C 21 \mathrm{CO}$ $\mathrm{M}=\mathrm{F} \& \mathrm{I} 21 \mathrm{DBN}=\mathrm{KRZN} \& \mathrm{P} 21 \mathrm{DBN}=\mathrm{KRZN} \& \mathrm{~S} 2$ $1 \mathrm{FMT}=\& \mathrm{~S} 21 \mathrm{ALL}=\& Z 21 \mathrm{ID}=\& \mathrm{~S} 21 \mathrm{CNR}=30$

Korodenko, M. (2019). Alphabet for the director: the quality of education, prepared by M. Korodenko. Education of Ukraine, 31/32, 12 August

6. https://mon.gov.ua/storage/app/media/Serpneva $\% 20$ conferentcia/Abetka_dlya_Dyrektora_2020 _compressed.pdf

Korsak, K. (2020). Quality of education and standards in the XXI century: myths and realities: 7 countries took part in the measurements: Ukraine, Belarus, Bosnia and Herzegovina, Brune Darussalam, Morocco, Philippines and Saudi Arabia. High school, 1, 93-107, http://presa.ua/vischa-shkola.html

Labus, N.A. (2018). Evaluating the quality of educational activities. School management, $31 / 32 / 33$, 60-62, https://journal.osnova.com.ua/journal/1-

Управління_школою

Plaskura, P. (2018). Assessing the Quality of the Didactic Process on the Dase of Its Monitoring With the Use of ICT. Pedagogical sciences: theory, history, innovative technologies, 2 (76). 185-197, https://library.sspu.edu.ua/wpcontent/uploads/2018/06/Ped_nauki_2_2018.pdf Pshenichnaya, L.V. (2019). Innovative management is a complex component of the quality of education. Management of higher and secondary education: a monograph / ed. O.V. Mikhailichenko. Saarbrucken: LAP LAMBERT Academic Publishing, 37-77, https://repository.sspu.edu.ua/bitstream/123456 789/7699/1/Михайличенко\%20О.\%20Управле ние.pdf

Shulikin, D. (2018). Quality monitoring. Education of Ukraine, 16, 8, https://core.ac.uk/download/pdf/231761568.pdf Sikorsky, P. (2019). The quality of secondary education is the main factor of quality higher education. High school, 4, 7-21, http://library.sspu.edu.ua/wpcontent/uploads/2019/10/Navchalno-vyhovnyjproczes.pdf

Us, M. (2018). Social Partnership as a Necessary Condition for Internal Education Quality Assurance in the Higher Education Institution. Pedagogical sciences: theory, history, innovative technologies, 10(84), 199-215, https://pedscience.sspu.sumy.ua/wpcontent/uploads/2019/04/19-1.pdf

Zabolotna, O.A. (2014). Educational Effectiveness Andquality Assurance in Alternative Education. Pedagogical sciences: theory, history, innovative technologies, 9(43), 224-237, https://library.sspu.edu.ua/wpcontent/uploads/2020/06/ped.-

nauky_2_2020.pdf

Zhitnik, B.O. (2020). About existing traditional and alternative means of assessing the quality of education. School management, 19/21, 17-29, https://journal.osnova.com.ua/journal/1Управління_школою 